\title{
BIODEGRADASI BAHAN ORGANIK OLEH MIKROBA DAN PENGARUHNYA TERHADAPTANAMAN PADI DI LAHAN GAMBUT
}

\section{BIODEGRADATION OF ORGANIC MATTER BY MICROBES AND ITS EFFECT ON PADDY PLANT IN PEAT LAND}

\author{
Mukhlis*) \\ Diterima 14 Maret 2014, disetujui Nopember 2014
}

\begin{abstract}
Organic matter as a source of organic fertilizer is very useful to increase agricultural production, decrease environmental pollutants, and increase land quality. This research aims to understand the roles of microbes on organic matter degradation and the effects on paddy plant in peat land. The research was conducted in the peat land of Liang Anggang village, Landasan Ulin subdistrict, Banjarbaru District, South Kalimantan province in the dry season 2010. There were two steps of experiment, i.e: (1) degradation of organic matter (composting) by using biodecomposer Mdec (consortia of decomposer microbes) and Trichoderma; (2) effects of biocompost on paddy plant. Treatments were biocompost (Mdec), biocompost (Trichoderma), and without compost (farmer's method) and arranged by using a randomized completely block design with five replications. Research results showed that biocompost quality made by using Mdec was better than that of Trichoderma-degraded one. Composting process using Mdec decreased C/N ratio from 43.32 to 17.30 within two weeks. At the same time, C/N ratio of biocompost made by using Trichoderma was still high (35.00). Biocompost (Mdec) gave the highest paddy yield $(3.50 \mathrm{t} / \mathrm{ha})$, while biocompost (Trichoderma) and no compost treatments gave paddy yield as much as $3.32 \mathrm{t} / \mathrm{ha}$ and 2.96 tha respectively.
\end{abstract}

Keywords: Biocompost, organic matter, paddy, peat land

\section{PENDAHULUAN}

Peran bahan organik tanah dalam budidaya tanaman sudah lama diketahui. Sumber bahan organik dapat berupa limbah hasil pertanian, limbah kota maupun limbah industri. Bahan organik sebagai sumber pupuk organik sangat bermanfaat bagi peningkatan produksi pertanian baik kualitas maupun kuantitas, mengurangi pencemaran lingkungan, dan meningkatkan kualitas lahan secara berkelanjutan (Simanungkalit et al., 2006). Pembangunan pertanian dimasa depan dihadapkan kepada permasalahan permintaan produk pertanian terutama pangan yang semakin meningkat sejalan dengan meningkatnya pertambahan penduduk yang diperkirakan pada tahun 2030 mencapai 300 juta jiwa (Pasaribu, 2008), sementara kapasitas sumberdaya alam pertanian terutama lahan terbatas dan bahkan semakin menurun karena konversi lahan pertanian ke non pertanian terus berlanjut. Setiap tahun sekitar 100.000 hektar lahan sawah produktif terutama di P. Jawa dikonversi untuk kegiatan nonpertanian (Manan, 2008).

Pemanfaatan lahan gambut sebagai areal produksi pertanian terutama pangan merupakan alternatif yang sangat strategis untuk menggantikan lahan

\footnotetext{
*) Balai Penelitian Pertanian Lahan Rawa, Jl. Kebun Karet, Loktabat Utara, Banjarbaru, Kalsel email: Mukhlisbalittra@yahoo.com
} 
pertanian yang terus berkurang akibat alih fungsi lahan. Potensi lahan gambut di Indonesia cukup luas diperkirakan antara 17,4 - 20,0 juta hektar yang tersebar di Kalimantan, Sumatera dan sebagian Papua (Radjagukguk, 2005; Notohadiprawiro, 1996). Hasil evaluasi dan inventarisasi lokasi-lokasi pemukiman transmigrasi di Indonesia menunjukkan bahwa lokasi pemukiman transmigrasi di lahan gambut dangkal telah berkembang menjadi lahan pertanian produktif yang menghasilkan bahan pangan, hortikultura, dan tanaman industri (Sardjadidjaja dan Sitorus, 1997).

Permasalahan pada tanah gambut dalam budidaya padi adalah kesuburan rendah, kemasaman tinggi dan adanya asam-asam organik hasil dekomposisi anaerob yang bersifat racun bagi tanaman. Menurut Abdurachman et al. (1998), pemanfaatan gambut untuk pertanian harus didasarkan pada konsep penyehatan tanah lebih dahulu. Konsep penyehatan tanah gambut dapat dilaksanakan melalui pemberian bahan amelioran. Ameliorasi tanah gambut bermanfaat untuk menekan kadar asam organik yang beracun, memperbaiki $\mathrm{pH}$ tanah, serta meningkatkan ketersediaan hara melalui perbaikan tapak jerapan tanah gambut. Bahan organik merupakan salah satu bahan amelioran yang dapat digunakan (Subiksa, 2000). Bahan organik baik berupa pupuk kandang maupun kompos dapat meningkatkan $\mathrm{pH}$ tanah dan mengandung unsur hara makro dan mikro sehingga dapat menurunkan penggunaan pupuk kimia yang diperlukan tanaman (Balittra, 2009). Disamping itu, pemanfaatan lahan secara intensif untuk tanaman semusim sepanjang tahun perlu diimbangi dengan pemberian bahan organik yang memadai untuk mempertahankan kandungan bahan organik tanah. Tanpa bahan organik, kesuburan tanah akan menurun meskipun pupuk anorganik diberikan dengan takaran tinggi (Karama et al., 1990).

Mengingat pentingnya bahan organik dalam budidaya padi dan dalam rangka menuju sistem budidaya yang ramah lingkungan, maka peman- faatan sumber bahan organik dari sumberdaya pertanian in situ merupakan alternatif dan tantangan untuk dikembangkan. Gulma yang melimpah pada saat pembersihan lahan menjelang musim tanam padi di lahan gambut dapat dimanfaatkan sebagai sumber bahan organik untuk dijadikan pupuk organik. Bahan organik yang diberikan ke dalam tanah harus memiliki $\mathrm{C} / \mathrm{N}$ rendah (Dalzell et al., 1987). Harada et al. (1993) melaporkan bahwa bahan organik segar yang langsung diberikan ke dalam tanah akan merugikan pertumbuhan tanaman karena terjadi immobilisasi nitrogen dan adanya senyawa-senyawa fitotoksik yang mengganggu tanaman.

Bahan organik memerlukan proses dekomposisi lebih dahulu untuk menghasilkan nisbah $\mathrm{C} / \mathrm{N}$ rendah. Proses tersebut dapat berlangsung secara aerobik maupun anaerobik dengan menghasilkan produk akhir yang disebut kompos. Proses pengomposan umumnya membutuhkan waktu yang relatif lama tergantung metoda penanganannya dan komposisi kimia bahan organik (terdapatnya senyawa-senyawa yang sulit terdekomposisi seperti selulosa dan lignin yang tinggi). Semakin tinggi rasio $\mathrm{C} / \mathrm{N}$ bahan organik maka proses pengomposan atau degradasi bahan semakin lama. Waktu yang dibutuhkan bervariasi dari satu bulan hingga beberapa tahun (Simanungkalit $e t$ al., 2006). Dengan demikian upaya pemanfaatan bahan organik pada lahan-lahan pertanian mengalami hambatan, apalagi jika dihadapkan dengan masa tanam yang mendesak untuk menghasilkan produksi tinggi, sering dianggap kurang ekonomis dan tidak efisien. Residu bahan organik sulit untuk dikonversi menjadi bentuk yang lebih berdayaguna karena degradasi lignin merupakan tahapan pembatas bagi kecepatan dan efisiensi degradasi yang berhubungan dengan selulosa, sehingga diperlukan upaya untuk mem-percepat degradasi lignin dan selulosa dengan menggunakan mikroba pendegredasi bahan organik (dekomposer). Saat ini telah beredar produk decomposer 'Mdec' dan 'Trichoderma' yang dapat dimanfaatkan untuk mempercepat proses 
degredasi bahan organik. Mdec adalah konsorsia mikroba pendegradasi bahan organik yang dihasilkan oleh Balai Penelitian Tanah (Badan Litbang Pertanian), sedangkan Trichoderma adalah jamur pendegredasi bahan organik yang dihasilkan oleh Balai Proteksi Tanaman Pangan dan Hortikultura Kalimantan Selatan.

Penelitian ini bertujuan untuk mengetahui peran mikroba dalam degradasi bahan organik dan pengaruhnya terhadap tanaman padi di lahan gambut.

\section{BAHAN DAN METODE}

Penelitian dilaksanakan pada musim kemarau tahun 2010 di lahan rawa gambut, desa Liang Anggang, Kecamatan Landasan Ulin, Kota Banjarbaru (Kalsel). Penelitian dilakukan melalui dua tahapan, yaitu:

\section{Degredasi bahan organik (pengomposan)}

Bahan organik yang digunakan berasal dari jerami padi dan gulma in situ serta menggunakan dua macam bahan dekomposer, yaitu Mdec dan Trichoderma. Komposisi kompos terdiri dari jerami padi ( $2 / 3$ bagian), enceng gondok (1/6 bagian) dan kotoran sapi (1/6 bagian). Proses pengomposan dimulai dengan mencacah jerami dan enceng gondok menjadi ukuran lebih kecil, kemudian ditumpuk dengan ukuran satu meter persegi dan disiram dengan larutan M.dec atau Trichoderma pada setiap lapisan sampai tinggi tumpukan kurang lebih satu meter. Setelah itu, tumpukan bahan organik ditutup dengan plastik dan diinkubasi selama 15 hari. Setiap minggu dibolak-balik untuk menciptakan aerasi dan penyiraman dilakukan apabila diperlukan. Pengamatan dilakukan terhadap perubahan $\mathrm{C} / \mathrm{N}$ ratio.

\section{Pengaruh kompos terhadap tanaman padi}

Perlakuan terdiri atas: 1) Biokompos (Mdec), 2) Biokompos (Trichoderma) dan 3) Tanpa kompos (cara petani). Perlakuan disusun dalam rancangan acak kelompok dengan 3 ulangan. Ukuran petak
$10 \mathrm{~m} \times 30 \mathrm{~m} /$ unit percobaan. Dosis pupuk anorganik adalah $1 / 2$ dosis anjuran yaitu: $60 \mathrm{~kg} \mathrm{~N} / \mathrm{ha}, 45 \mathrm{~kg}$ $\mathrm{P}_{2} \mathrm{O}_{5} /$ ha dan $45 \mathrm{~kg} \mathrm{~K}$ O/ha, kapur (dolomit) 1000 $\mathrm{kg} / \mathrm{ha}$, sedangkan bahan organik (biokompos) $2 \mathrm{t} /$ ha. Dosis pupuk anorganik cara petani adalah 200 kg NPK phonska/ha dan $175 \mathrm{~kg}$ N/ha. Bahan organik dan kapur diberikan 2 minggu sebelum tanam dengan cara disebar merata. Pupuk $\mathrm{P}_{2} \mathrm{O}_{5}$ dan $\mathrm{K}_{2} \mathrm{O}$ diberikan pada umur tanaman 1 minggu, sedangkan pupuk $\mathrm{N}$ diberikan 2 kali yaitu sebagian pada umur tanaman 1 minggu dan sisanya pada umur tanaman 3 minggu. Bibit padi (varietas Ciherang) umur 3 minggu ditanam pada jarak $25 \times 25 \mathrm{~cm}$ dengan 2 batang per lubang. Pemeliharaan berupa penyiangan dilakukan pada umur tanaman 3 minggu. Pengamatan meliputi analisa tanah awal, analisa kandungan hara bahan organik yang digunakan, pertumbuhan tanaman (tinggi tanaman, jumlah anakan maksimum), komponen hasil (panjang malai, jumlah gabah isi per malai, persen gabah isi dan berat 100 biji gabah) dan hasil padi per hektar, yang dikonversi dari hasil ubinan $\left(6 \mathrm{~m}^{2}\right)$. Data dianalisa sidik ragam dengan menggunakan uji F, kemudian dilanjutkan uji beda rata-rata untuk mengetahui pengaruh masingmasing perlakuan.

\section{Hasil dan Pembahasan}

\section{Degradasi Bahan Organik (kompos)}

Sifat kimia awal dari campuran komposisi bahan organik disajikan pada Tabel 1. Sifat kimia (kualitas kimia) bahan organik mempengaruhi kecepatan dekomposisi bahan organik. Kualitas bahan organik diantaranya ditentukan oleh rasio $\mathrm{C} / \mathrm{N}$, kandungan $\mathrm{N}_{\text {total }}, \mathrm{P}_{\text {total }}$ dan lignin serta polifenol (Swift dan Woomer, 1993). Degradasi (pengomposan) bahan organik merupakan suatu proses fisik maupun kimia bahan organik menjadi senyawa kimia lainnya oleh aktivitas mikrooganisme (Sarief, 1986). Kecepatan degradasi bahan organik dipengaruhi oleh (1) susunan kimia bahan organik, (2) struktur fisik sisa tanaman, (3) aktivitas mikroorganisme dan (4) kondisi lingkungan (Brussard, Hauser dan Tian, 1993). 
Menurut Tian (1992) kualitas bahan organik atau komposisi kimia bahan organik merupakan faktor kritis yang mempengaruhi dekomposisi dan mineralisasi unsur hara.

Tabel 1. Sifat kimia campuran bahan organik (bahan kompos) sebelum pengomposan

\begin{tabular}{lc}
\hline Sifat kimia & $\begin{array}{c}\text { Bahan } \\
\text { Kompos }\end{array}$ \\
\hline C-organik (\%) & 47,52 \\
N-total (\%) & 1,12 \\
Rasio C/N & 43,32 \\
$\mathrm{P}_{2} \mathrm{O}_{5}(\%)$ & 0,608 \\
$\mathrm{~K}_{2} \mathrm{O}(\%)$ & 2,776 \\
\hline
\end{tabular}

Karakteristik kimia kompos yang dihasilkan dari 2 dekomposer (Mdec dan Trichoderma) disajikan pada Tabel 2. Kualitas kompos pada perlakuan dekomposer Mdec lebih baik dibandingkan pada dekomposer Trichoderma. Pada perlakuan Mdec proses pengomposan berjalan lebih cepat yaitu terlihat pada penurunan rasio $\mathrm{C} / \mathrm{N}$ kompos dari 43,32 menjadi 17,30 dalam waktu 2 minggu. Hasil ini sesuai dengan laporan Sarlan dan Mejaya (2013) bahwa jerami padi yang dikomposkan dengan Mdec dapat menurunkan $\mathrm{C} / \mathrm{N}$ ratio dari 50,93 menjadi 18,54. Uji laboratorium menunjukkan bahwa dekomposer Mdec mengandung Lactobacillus sp, Actinomycetes sp, Streptomycetes sp, dan Rhizobium sp. Sedangkan pada perlakuan dekomposer Trichoderma, proses pengomposan sampai 2 minggu ternyata masih memperlihatkan $\mathrm{C} / \mathrm{N}$ ratio yang tinggi $(35,00)$ dan dianggap belum matang. Kandungan unsur hara antara dekomposer Mdec dengan Trichoderma juga berbeda, terutama kandungan $\mathrm{C}_{\text {org }}, \mathrm{N}_{\text {total }}$ dan $\mathrm{P}_{\text {total }}$. Berdasarkan standar kualitas kompos Asosiasi Bark Compos Jepang, kompos tersebut sudah memenuhi standar dengan kriteria sebagai berikut: N-total $>1,2 \%, \mathrm{C} / \mathrm{N}<35 \%, \mathrm{P}_{2} \mathrm{O}_{5}>0,5 \%$, $\mathrm{K}_{2} \mathrm{O}>0,3 \%$ (Harada et al., 1993).

\section{Pengaruh kompos terhadap tanaman padi}

\section{a. Karakteristik Tanah}

Lokasi penelitian termasuk dalam kategori gambut lebak. Hasil analisis tanah menunjukkan bahwa tanah tergolong gambut dengan tingkat kesuburan relatif rendah, karena $\mathrm{pH}$ tanah tergolong masam, $\mathrm{C} / \mathrm{N}$ ratio sangat tinggi, $\mathrm{K}$ tersedia tergolong rendah, $\mathrm{Ca}$ dan $\mathrm{Mg}$ sedang, sedangkan Fe dan sulfat tergolong tinggi untuk tanaman padi unggul (Tabel 3). Lahan gambut tersebut baru dibuka sekitar 5 tahun, dan selama 2 tahun terakhir lahan tidak digunakan (bera). Vegetasi yang tumbuh dominan berupa pakispakisan. Di lokasi penelitian belum terdapat tata air, sehingga sumber air hanya mengandalkan dari curah hujan yang ada.

Tabel 2. Karakteristik Kimia Kompos dengan Dua Jenis Dekomposer

\begin{tabular}{lcc}
\hline \multirow{2}{*}{ Karakteristik kimia kompos } & \multicolumn{2}{c}{ Jenis dekomposer } \\
& M. Dec & Trichoderma \\
\hline pH $\mathrm{H}_{2} \mathrm{O}$ & 8,90 & 8,84 \\
C-organik (\%) & 25,67 & 44,10 \\
$\mathrm{~N}$-total (\%) & 1,48 & 1,26 \\
$\mathrm{C} / \mathrm{N}$ & 17,30 & 35,00 \\
$\mathrm{P}_{2} \mathrm{O}_{5}(\%)$ & 0,61 & 0,56 \\
$\mathrm{~K}_{2} \mathrm{O}(\%)$ & 0,93 & 0,93 \\
$\mathrm{Ca}(\%)$ & 1,54 & 1,68 \\
$\mathrm{Mg}(\%)$ & 0,24 & 0,28 \\
Kadar air & 307,63 & 339,00 \\
\hline
\end{tabular}




\section{b. Pertumbuhan tanaman}

Secara umum pertumbuhan tanaman padi varietas Ciherang di lahan gambut lebih rendah dibandingkan potensinya. Berdasarkan deskripsi, padi varietas Ciherang mempunyai tinggi $107-115 \mathrm{~cm}$ dan jumlah anakan produktif $14-17$ batang (Puslitbangtan Pangan, 2013). Pada penelitian ini, tinggi tanaman berkisar antara $68-80 \mathrm{~cm}$ dan jumlah anakan produktif antara 10-12 batang. Rendahnya pertumbuhan tanaman ini dimungkinkan karena kondisi lahan gambut yang mempunyai tingkat kesuburan rendah, sedangkan penambahan dosis pupuk dan biokompos belum optimal. Meskipun demikian, pertumbuhan tanaman pada akhir vegetatif menunjukkan adanya perbedaan antar perlakuan yang diberikan. Pemberian biokompos dapat memperbaiki pertumbuhan tanaman padi (Gambar 1). Pertumbuhan terbaik ditunjukkan oleh perlakuan biokompos (Mdec) diikuti perlakuan biokompos (Trichoderma), sedangkan tanpa kompos (cara petani) menunjukkan pertumbuhan yang paling terhambat. Jumlah anakan pada akhir vegetatif tidak memperlihatkan adanya perbedaan antar perlakuan, tetapi pada jumlah anakan produktif menunjukkan perbedaan yang nyata. Jumlah anakan produktif terbanyak ditunjukkan pada perlakuan biokompos (Mdec), sedangkan pada perlakuan biokompos (Trichoderma) dan tanpa kompos memperlihatkan jumlah anakan yang tidak berbeda (Gambar 2). Peningkatan per-

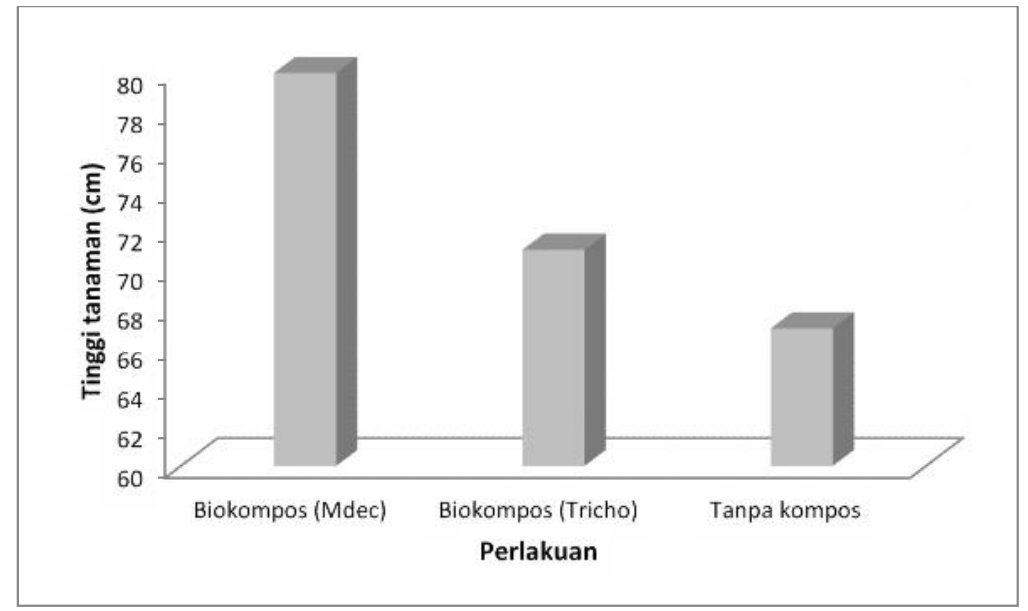

Gambar 1. Tinggi Tanaman Sampai Akhir Fase Vegetatif

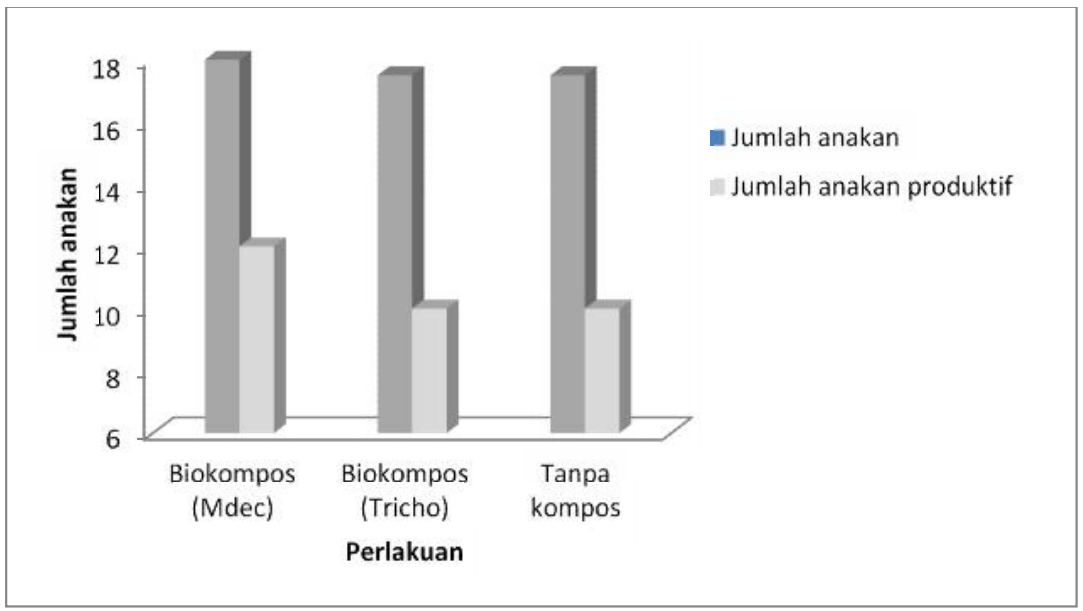

Gambar 2. Jumlah Anakan Pada Akhir Vegetatif dan Jumlah Anakan Produktif 
tumbuhan ini sejalan dengan kualitas biokompos (Mdec) yang mengandung unsur hara $\mathrm{N}$ dan $\mathrm{P}$ lebih tinggi dibandingkan biokompos(Trichoderma). Menurut Sarwani (1994) bahwa tanpa penambahan unsur hara makro dan mikro yang cukup, pertumbuhan tanaman di lahan gambut akan terhambat. Disamping itu, De Datta (1981) menyatakan bahwa unsur hara $\mathrm{P}$ yang diserap tanaman dapat meningkatkan pembentukan anakan produktif.

\section{c. Komponen Hasil dan Hasil}

Komponen hasil dan hasil padi pada setiap perlakuan disajikan pada Tabel 4. Perlakuan biokompos (Mdec) memperlihatkan rata-rata tertinggi pada persentase gabah isi, berat gabah/ rumpun, dan hasil gabah dan berpengaruh nyata dibandingkan perlakuan lainnya. Meskipun secara statistik tidak berbeda nyata, rata-rata jumlah gabah/malai tertinggi juga ditunjukkan oleh perlakuan biokompos (Mdec). Kondisi ini menunjukkan bahwa peningkatan pertumbuhan akibat perlakuan biokompos (Mdec) diikuti oleh peningkatan komponen hasil dan hasil padi (persentase gabah isi, berat gabah/rumpun, jumlah gabah/malai, dan hasil gabah). Menurut Cock dan Yoshida (1972) dalam Ismunadji dan Manurung (1988) bahwa sebanyak 68 persen hasil fotosintesa dari batang dan pelepah daun ditranslokasikan ke gabah. Sedangkan De Datta (1981) menyatakan bahwa unsur hara seperti $\mathrm{N}$ dan $\mathrm{P}$ yang diserap selama pertumbuhan vegetatif ditranslokasikan dari jaringan vegetatif ke biji setelah pembungaan. Perlakuan biokompos (Trichoderma) dan tanpa kompos memperlihatkan persentase gabah isi, berat gabah/rumpun, jumlah gabah/malai, dan hasil gabah yang lebih rendah. Hal ini mungkin disebabkan kandungan hara terutama $\mathrm{N}$ dan $\mathrm{P}$ yang lebih rendah, sehingga jumlah dan kualitas bulir menurun. Hasil pengamatan juga menunjukkan bahwa rata-rata panjang malai dan berat 100 biji kurang lebih sama antar perlakuan. Keadaan ini mungkin disebabkan kondisi pertumbuhan terutama tinggi tanaman dan jumlah anakan produktif yang lebih rendah dari potensinya, sehingga pembentukan malai dan gabah per satuan tidak optimal.

Berdasarkan Tabel 4 diketahui bahwa hasil gabah yang diperoleh berkisar antara 1,96 - 3,50 t/ha.

Tabel 3. Karakteristik Tanah Gambut Lokasi Penelitian, Ds. Lianganggang, Kec. Landasan Ulin, Kota Banjarbaru, MK 2010

\begin{tabular}{llrl}
\hline No & Parameter & Nilai & Kriteria \\
\hline 1. & pH $\mathrm{H}_{2} \mathrm{O}$ & 4,92 & Masam \\
2. & $\mathrm{N}(\%)$ & 0,45 & Sedang \\
3. & C-organik $(\%)$ & 30,03 & Tinggi \\
4. & C/N & 67,03 & Sangat Tinggi \\
5. & Ptotal $(\mathrm{mg} / 100 \mathrm{~g})$ & 45,37 & Tinggi \\
6. & Ktotal $(\mathrm{mg} / 100 \mathrm{~g})$ & 8,59 & Sangat rendah \\
7. & K-dd $(\mathrm{Cmol} / \mathrm{kg})$ & 0,21 & Rendah \\
8. & Na-dd $(\mathrm{Cmol} / \mathrm{kg})$ & 0,19 & Rendah \\
9. & Ca-dd $(\mathrm{Cmol} / \mathrm{kg})$ & 7,37 & Sedang \\
10. & Mg-dd $(\mathrm{Cmol} / \mathrm{kg})$ & 3,45 & Sedang \\
11. & Al-dd $(\mathrm{Cmol} / \mathrm{kg})$ & 0 & Rendah \\
12. & H-dd $(\mathrm{Cmol} / \mathrm{kg})$ & 0,3 & \\
13. & KTK $(\mathrm{Cmol} / \mathrm{kg})$ & 22,5 & Sedang \\
14. & Fe $(\mathrm{ppm})$ & 421,50 & Tinggi \\
15. & SO $(\mathrm{ppm})$ & 346,413 & Tinggi \\
& Tekstur & & Liat \\
& - pasir $(\%)$ & 8,56 & \\
& - debu $(\%)$ & 23,77 & \\
& - liat $(\%)$ & 67,67 & \\
\hline & & & \\
\hline
\end{tabular}


Tabel 4. Komponen Hasil dan Hasil Padi Akibat Pemberian Biokompos di Lahan Gambut, Desa Liang Anggang, Kec. Landasan Ulin, Kota Banjarbaru, MK 2010

\begin{tabular}{lcccccc}
\hline \multirow{2}{*}{ Perlakuan } & \multicolumn{6}{c}{ Komponen hasil } \\
\cline { 2 - 6 } & $\begin{array}{c}\text { Panjang } \\
\text { malai (cm) }\end{array}$ & $\begin{array}{c}\text { Gabah } \\
\text { isi/ malai }\end{array}$ & $\begin{array}{c}\text { Gabah } \\
\text { isi }(\%)\end{array}$ & $\begin{array}{l}\text { Berat gabah/ } \\
\text { Rumpun }(\mathrm{g})\end{array}$ & $\begin{array}{l}\text { Berat 100 } \\
\text { Biji }(\mathrm{g})\end{array}$ & Hasil (t/ha) \\
\hline M-dec & $21,95 \mathrm{a}$ & $78,33 \mathrm{a}$ & $83,23 \mathrm{a}$ & $26,16 \mathrm{a}$ & $2,75 \mathrm{a}$ & $3,50 \mathrm{a}$ \\
Trichoderma & $22,54 \mathrm{a}$ & $69,00 \mathrm{a}$ & $76,43 \mathrm{~b}$ & $20,58 \mathrm{~b}$ & $2,76 \mathrm{a}$ & $3,32 \mathrm{a}$ \\
Cara petani & $21,98 \mathrm{a}$ & $60,33 \mathrm{a}$ & $75,76 \mathrm{~b}$ & $20,19 \mathrm{~b}$ & $2,71 \mathrm{~b}$ & $1,96 \mathrm{~b}$
\end{tabular}

Keterangan: Angka sekolom yang diikuti huruf yang sama tidak berbeda nyata pada uji LSD $5 \%$

Perlakuan biokompos (Mdec) memperlihatkan hasil gabah tertinggi (3,50 t/ha) diikuti oleh biokompos (Trichoderma) dan tanpa kompos yaitu masingmasing 3,32 dan 1,96 t/ha. Meskipun demikian, hasil yang diperoleh ini masih dibawah potensi hasil padi varietas Ciherang dalam kondisi optimal yaitu 5-7 tha. Rendahnya hasil ini kemungkinan disebabkan kondisi lahan gambut yang tingkat kesuburannya rendah dan kekeringan karena penanamannya dilakukan pada musim kemarau.

\section{KESIMPULAN}

1. Kualitas biokompos dengan dekomposer Mdec lebih baik dibandingkan dekomposer Trichoderma. Pada perlakuan Mdec proses pengomposan berjalan lebih cepat yaitu terlihat pada penurunan rasio $\mathrm{C} / \mathrm{N}$ kompos dari 43,32 menjadi 17,30 dalam waktu 2 minggu. Sedangkan pada perlakuan dekomposer Trichoderma, proses pengomposan dalam waktu 2 minggu ternyata rasio $\mathrm{C} / \mathrm{N}$ masih tinggi $(35,00)$ dan masih belum matang.

2. Perlakuan pemberian biokompos (Mdec) mampu meningkatkan hasil padi di lahan gambut dengan produktivitas 3,50 t/ha. Sedangkan biokompos (Trichoderma) dan tanpa kompos hanya menghasilkan gabah masing-masing 3,32 t/ha dan 1,96 t/ha.

\section{DAFTAR PUSTAKA}

Abdurrachman, A., K. Sudarman, dan D.A. Suriadikarta. 1998. Pengembangan lahan pasang surut: Keberhasilan dan kegagalan ditinjau dari fisiko kimia lahan lahan pasang surut. Dalam Sabran, M. et al. (eds) Prosiding Seminar Nasional Hasil Penelitian Menunjang Akselarasi Pengembangan Lahan Pasang Surut. Balai Penelitian Tanaman Pangan Lahan Rawa. Banjarbaru.

Balittra. 2009. Laporan Tahunan Balittra. Balai Besar Penelitian dan Pengembangan Sumberdaya Lahan Pertanian, Balai Penelitian Pertanian Lahan Rawa. Banjarbaru.

Brussard, L., S. Hauser and G. Tian. 1993. Soil fauna activity in relations to sustainability of agricultural system in the humid tropic. In Mulungoy, K and R. Mercxl (eds). Soil Organic Matter Dynamics and Sustainability of Tropical Agriculture. IITA/K. U. Leuven, John Wiley \& Sons Ltd. Chichester.

Dalzell, H.W., A.J. Biddlestone, K.R. Gray, and K. Thurairajan. 1987. Soil management: Compost Production and Use In Tropical and Sub Tropical Environment. FAO, Rome. Soil Bull. 56:175-177.

De Datta, S.K. 1981. Principles and Practices of Rice Production. Jhon Wiley and Sons, New York 
Harada, Y., K. Haga, T. Osada, and M. Khosino. 1993. Quality of compost produced from animal wastes. J. JARQ 26(4):238-246.

Ismunadji, M. dan S.O. Manurung. 1988. Morfologi dan Fisiologi Padi. Buku 1. Badan Litbang Pertanian. Pusat Penelitian dan Pengembangan Pertanian Tanaman Pangan. Bogor

Karama, A.S., A.R. Marzuki, dan I. Manwan. 1990. Penggunaan pupuk organik pada tanaman pangan. Prosiding Lokakarya Nasional Efisiensi Penggunaan Pupuk. Pusat Penelitian Tanah dan Agroklimat. Hal. 395-425.

Manan, H. 2008. Strategi dan arah program pencetakan sawah baru. Dalam Subarja, D.S. et al. (eds). Prosiding Seminar Nasional Sumberdaya Lahan dan Lingkungan Pertanian. 7-8 Nopember. Buku I. Balai Besar Litbang Sumberdaya Lahan Pertanian Badan Litbang Pertanian Dep. Pertanian. Bogor.

Notohadiprawiro, T. 1996. Constraints to achieving the agricultural potential of tropical peatlands an Indonesian prespective. In Maltby, E. et al. (eds). Tropical Lowland Peatlands of Southeast Asia. P: 139-154.

Pasaribu, B. 2008. Implikasi UU Lahan Pertanian Pangan Abadi Terhadap Ketahanan Pangan Nasional. Dalam D.S. Subarja et al. (eds) Prosiding Seminar Nasional Sumberdaya Lahan dan Lingkungan Pertanian. 7-8 Nopember. Buku I. Balai Besar Penelitian dan Pengembangan Sumberdaya Lahan Pertanian Badan Litbang Pertanian Dep. Pertanian. Bogor.

Puslitbangtan Pangan. 2013. Deskripsi Padi Varietas Ciherang.www.puslitan.bogor.net/index.php. Diakses 10 Desember 2013.

Radjagukguk, B. 2005. Penggunaan lahan gambut tropik secara bijaksana (perspektif pertanian). Makalah disampaikan pada Semnas Himpunan Gambut Indonesia, 2021 September. Palangkaraya.

Sardjadidjaja,R. dan S.R.P. Sitorus. 1997. Pemanfaatan lahan gambut untuk pemukiman transmigrasi: Prospek dan Permasalahannya. Prosiding Seminar Nasional Gambut II. 14-15 Januari 1997. Jakarta.

Sarief, S. 1986. Kesuburan dan Pemupukan Tanah Pertanian. Pustaka Buana. Bandung.

Sarlan, Adan M.J. Mejaya. 2013. Pengomposan jerami. Sinar Tani Edisi 22-28 Mei 2013 No. 3508.

Sarwani, M. 1994. Status hara gambut di Kalimantan Selatan. Dalam Budidaya Padi Lahan Pasang Surut dan Lebak. Buku I. Puslitbangtan, Balai Penelitian Tanaman Pangan Banjarbaru. Hal 123-126.

Simanungkalit,R.D.M., D.A.Suriadikarta, R. Saraswati, D.Setyorini, dan W. Hartatik. 2006. Pupuk Organik dan Pupuk Hayati. Balai Besar Litbang Sumberdaya Lahan Pertanian. Badan Penelitian dan Pengembangan Pertanian. Bogor.

Subiksa, I.G.M. 2000. Ameliorasi Lahan Gambut untuk Usahatani yang Berkelanjutan. Prosiding Semnas Penelitian dan Pengembangan Pertanian di Lahan Rawa. 25-27 Juli. Cipayung.

Swift, M.J dan P. Woomer. 1993. Organic matter and the sustainability of agricultural system definition and measurement. In Mulungoy, $\mathrm{K}$ and R. Mercxl (eds). Soil Organic Matter Dynamics and Sustainability of Tropical Agriculture. IITA/K. U. Leuven, John Wiley \& Sons Ltd. Chichester.

Tian, G. 1992. Biological effect of plant residues with contransting chemical composition on plant and soil under humid condition. Ph.D thesis. Wageningen Agricultural Faculty. 